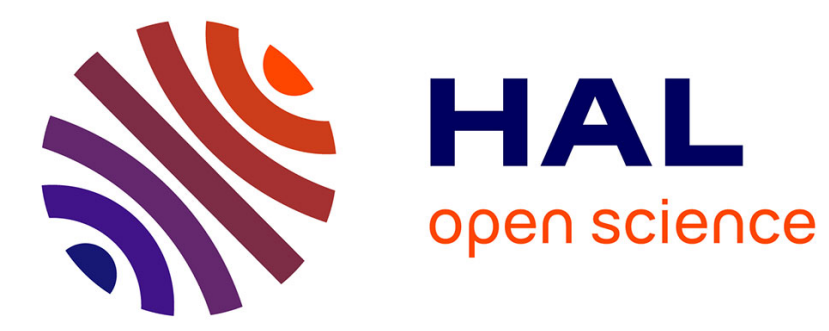

\title{
The economy of 1950s popular French cinema
}

Frédéric Gimello-Mesplomb

\section{- To cite this version:}

Frédéric Gimello-Mesplomb. The economy of 1950s popular French cinema. Studies in French Cinema, 2006, 6 (2), pp.141-150. halshs-01808380

\section{HAL Id: halshs-01808380 \\ https://shs.hal.science/halshs-01808380}

Submitted on 19 Aug 2018

HAL is a multi-disciplinary open access archive for the deposit and dissemination of scientific research documents, whether they are published or not. The documents may come from teaching and research institutions in France or abroad, or from public or private research centers.
L'archive ouverte pluridisciplinaire HAL, est destinée au dépôt et à la diffusion de documents scientifiques de niveau recherche, publiés ou non, émanant des établissements d'enseignement et de recherche français ou étrangers, des laboratoires publics ou privés. 


\title{
The economy of 1950s popular French cinema
}

\section{Frédéric Gimello-Mesplomb}

\author{
Keywords \\ 1950 s \\ French popular cinema \\ film support policy
}

Studies in French Cinema Volume 6 Number 2

doi: $10.1386 /$ sfci.6.2.141/1

\begin{abstract}
Cinema was a major cultural issue in France of the 1950s, even if the film industry was in crisis. The number of films increased, but the audiences had been in decline from 1947-1952 when figures reached their lowest since the Liberation. The Blum-Byrnes agreements, signed in 1946, accentuated this decline. The quotas operating at the time (four weeks per quarter for French films and eight weeks for American films) meant that French films aimed to make a profit very rapidly in the first week of screening so as to make way for others. Popular French cinema emerged from this combination of attendance/overproduction/quotas. This combination pushed French producers toward thematic and aesthetic formulas aiming at rapid product placement so as to compete with American films. To remedy this situation, the French government passed a law in 1948 whose aim was to help re-energize the ailing French film industry with the help of public funds. With the principle of equality for the producers in mind, the redistribution of funds was based pro-rata on the boxoffice success of the previous film. This article demonstrates the links between this system and the growth of popular cinema. It is particularly because of the proliferation of popular films that critics and cinephiles mobilized in 1953 to obtain the creation of new fund to support 'quality'. The concept of quality in film was consequently defined during the 1950s as a function of the commercial success of popular cinema.
\end{abstract}

Up until the 1950s at least, the French way of life was virtually indistin- guishable from that of the 1930s. This has led a number of historians to indicate this continuity with phrases like 'the fifteen years of the 1930s', or 'the thirty years of the 1930s' (to refer to the condition of French society through to the 1960s). Although this idea of continuity prevails in research done on the 1950s (Rioux 1983), there is in fact not much in-depth research into this period. What studies there are point to a complex social and political situation, and for some this concept of linearity is fairly relative. Thus, for Pierre Mayol, the crucial period 1944-54 is troubled, since it is made up of two completely opposing blocs: first there was rationing (until 1947), followed by production from 1949 onwards; and then, second, practices changed from 1950, with consumerism the main focus (Mayol 1995). Thus we witness a passage from a period of deprivation to one of the pursuit of comfort, linked of course to the return of consumerism and purchasing power brought about by the economic recovery.

The period in question is a troubled one because this passage was not smooth (see Eveno 1985). It happened in two phases. Political debate was divided. One section of the political class supported Pierre Mendès-France who, at first, embodied the rigour necessary for recovery, as opposed to the more flexible approach embodied by René Pleven (see Heinz and Peterson 1974). The French Communist Party (PCF), through the voice of its leader, Maurice Thorez, contributed to this debate. Thorez, in a well-known speech to miners in Waziers (Pas-de-Calais) on 21 July 1945, pointed to one possible line of conduct with his slogan, 'Production is today the high- est form of the class struggle and the duty of the French people' (Thorez 1964: 171). This was not a view 
unanimously held within the PCF, how- ever. The government came down on the side of production. The first five- year plan, negotiated by Jean Monnet, gave priority to the mass production of coal and steel, as well as the updating of agricultural machinery, public transport and energy at the expense of culture - which has always remains the luxury of the more privileged. Thus the cultural well-being of the nation was put aside until better times, the very times that mark the second phase of this period. For Pierre Mayol 'up until 1949, the French were primarily concerned about the future of the nation; it was only after 1949 that they became interested in their own well-being' (Mayol 1995: 17).

The situation changed in 1950. There was a stable average of 840,000 births per year through until the 1970s, and during the same period the GNP went up by 49 per cent. The rise in purchasing power was therefore very favorable to the acquisition of commodities such as radios and televisions: growth went from 5,345,942 radios in 1945 to $6,889,522$ in 1950 and then to 9,266,464 in 1955 for approximately 14 million homes, doubling in ten years (Brochand 1994). Compared to the radio, television sales were somewhat slower in relative terms. A television set was still a luxury item in the 1950s. In 1949 there were 297 televisions, 3,794 in 1951, 10,558 in 1952, 24,209 in 1953, 59,971 in 1954, 125,088 in 1955 and finally 260,508 in 1956 (which represents only 2 per cent of French homes) (Levy 1999). Technological development and broadcasting standardization contributed massively to the huge growth in the consumption practices of images and sound. The term 'culture industries' began to be used, just as tourism and mass leisure became key realities in the 1960s (Guillaume 1989). During the 1950s, culture became a crucial issue. According to Pascale Goetschel and Emmanuelle Loyer, it is the 'subject of many and diverse discussions about its trans- mission practices and its democratizing effects. This cultural discourse takes on an importance heretofore unknown, both in the institutional framework and more radical arenas, and sets the tone for this decade' (Goetschel and Loyer, 1994).

It is within this context that cinema became a cultural issue of prime importance. Immediately after the war, cinema was the leading leisure activity as far as entertainment was concerned in France, but the frequency of attendance was in progressive decline from 1947 onwards until 1952 when audience figures reached their lowest since the Liberation. The decrease was so remarkable that in 1953 the Hachette Almanac declared: 'Fewer and fewer spectators. Darkened theatres have seen their clientele decline. Whereas on average in 1948 the French went to the cinema ten times per year, now they only go nine times. Why?' (Mayol 1995: $31)$.

\begin{tabular}{lllll}
\hline & $\begin{array}{l}\text { Number of } \\
\text { films } \\
\text { in France }\end{array}$ & $\begin{array}{l}\text { Number of } \\
\text { first films }\end{array}$ & $\begin{array}{l}\text { Budiences } \\
\text { in millions }\end{array}$ & $\begin{array}{l}\text { Boffice } \\
\text { receipts } \\
\text { infrancs } \\
\text { (millions) }\end{array}$ \\
\hline 1945 & 73 & 6 & 380 & 7,386 \\
1946 & 91 & 8 & 369 & 10,386 \\
1947 & 71 & 15 & 423 & 13,885 \\
1948 & 92 & 11 & 402 & 19,566 \\
1949 & 108 & 20 & 388 & 22,170 \\
1950 & 117 & 15 & 371 & 25,861 \\
1951 & 107 & 21 & 373 & 32,254 \\
1952 & 109 & 11 & 360 & 38,382 \\
1953 & 112 & 12 & 371 & 41,422 \\
1954 & 98 & 9 & 383 & 45,500 \\
1955 & 110 & 9 & 395 & 48,200 \\
1956 & 129 & 17 & 399 & 50,000 \\
1957 & 142 & 13 & 412 & 54,800 \\
1958 & 126 & 13 & 371 & 59,500 \\
\hline
\end{tabular}


A combination of several factors can serve to explain this situation, which might otherwise seem paradoxical, given the economic indicators. First, the drop in attendance is proportionally the inverse of films on offer (see Table 1 above). Indeed, although there were only 73 French films in 1945, this grew to 108 in 1949 and stabilized around that number up until 1958 (see Virenque 1990).

Second, the French box office was on the increase. Technological innovations such as Technicolor, 3D and Cinemascope (1953) were introduced in the hope of attracting audiences back to film theatres (see Vincent 1977). These innovations did not man- age to attract new audiences, but they did help to maintain existing audience figures at around the 380 million mark. Exhibitors raised the price of their tickets to make up for the shortfall in numbers.

It also needs to be pointed out that audiences were not limited to the French films on offer; there were others, especially American and Italian films. In fact, revenue for French films was on the decline despite the audience figure of 380 million. Far from indicating a success for popular French cinema, this figure is very clearly linked to the appeal of American films which had recently been released in France thanks to the Blum-Byrnes agreement of 1946. A total of 182 American films were screened in France in 1946 and no less than 338 in the first six months of 1947. French film producers set about increasing their outputs in an attempt to capture audiences. The quotas operating at the time (four weeks per quarter for French films and eight weeks for American films) meant that French films aimed to make a profit very rapidly in the first week of screening so as to make way for others. French popular cinema emerged from this equation of frequentation/ overproduction/quotas - an equation that would push French producers toward thematic and aesthetic formulas aiming at a fast and viable placement of their products that would fill the competitive gap (with American films) and produce the desired economic results during that crucial first week of exhibition.

A second factor, political this time, contributed to the success of the popular French cinema of the 1950s. In the two years that followed the implementation of the quotas (linked to the Blum-Byrnes agreement), industrial action and public demonstrations obliged the government to pass a law, in July 1948, which put in place a 'temporary aid to film production', whose aim was to help re-energize the ailing French film industry. ${ }^{1}$ This law, which was improved upon in 1953, 1955 and 1959, set in place the foundations of what is considered today as one of the pillars of the 'cultural exception' that is French cinema. The aid system is simple: it consists in raising a levy of 10.9 per cent on all ticket sales (called TSA: Taxe supplémentaire additionnelle) which goes into a special fund (the Fonds d'aide à l'industrie cinématographique, also known as Fonds de soutien), whose special function is the redistribution of money within the creative section of the industry. With the principle of equality for the producers in mind, the redis- tribution is based pro-rata on the box-office success of the previous film. Aid is therefore automatic. The professionals in the industry naturally approved of this system, even if it was deemed unpopular by film-makers because it seemed close to forced borrowing (you could only get it if you were already successful and so you would be forced to continue with similar successes). At any event, the demonstrations came to an end, and production resumed. However, this measure ended up by encouraging film producers to opt for films with popular topics.

Indeed, this automatic redistribution very quickly established a sort of closed circuit: a successful film using popular themes will automatically guarantee directors a generous budget for the next film, since they will be able to draw on the levies awaiting them in the Fonds de soutien. This auto- matic aid sanctions aesthetic and narrative film practices that dominate productions made during the quota period, in other words those which are most viable. Thus, the establishing of state support for the cinema brought about the opposite effect from the one initially intended in 1948: 
because money attracts money, it was impossible for the Fonds de soutien to be of any assistance to film-makers who were struggling financially after a flop (certain films objectively considered to have success written all over them could also be huge flops). This was equally the case for film-makers wish- ing to embark on a first film. They were not entitled to apply for funding for the simple reason that they had no previous film.

Despite these shortcomings, French cinema rallied and production went on the increase thanks to this aid system: 91 films were made in 1948, 107 in 1949, 117 in 1950. These are essentially films that can be labelled 'popular'. If the term 'popular' is still a debatable one today, the official list of films given a shooting visa by the Centre National de la Cinématographie (CNC) between 1947 and 1956 provides a partial response: the most frequent are costume comedies, romantic dramas and operettas, in other words, the genres which, at the time, attracted audiences most. These genres were not new and they confirm the continuity in themes treated during the Second World War. As early as February 1941, Continental, a German studio based in Paris - but nonetheless a studio à la française albeit controlled by the Germans - produced films exalting romance, drama and historical reconstructions, all of which were inspired by France's past (see Berthin-Maghit 1994: 12). Far from attempting to function as propaganda in the obvious sense of the term, these films were intended to pacify civilians by playing the card of social consensus, thanks to the propagation of popular values so clearly liked and shared by the cinema-going public. This continuity with themes during the 1950s does give weight to Joël Magny's hypothesis of the 'thirty years of the 1930s', although a more nuanced view is given by film historian Yann Darré, who sees it rather as a case of 'continuity predominating' (Darré 2002: 73). The genres favoured by producers show extraordinary diversity, which has been oversimplified by the need of film historians to standardize and group disparate commodities.

First, there was the growth in popularity of the French thriller (the polar) which recycled aspects of the atmospheric noirish French films of the 1930s and the pulp-fiction American detective films of the post-war period. This category of film had a strong following which meant it could be widely distributed in local and suburban cinemas (see Berthet 2000: 117ff). If the French were initiated into the 'Série noire' novels thanks to films produced by Bernard Borderie, John Berry or Ralph Habib, they also became attracted to them thanks to the fetish film actor Eddie Constantine, and such films as Identité judiciaire/Paris Vice Squad (1951), La Môme vert-de-gris/Poison Ivy (1952) and Ça va barder/Give 'em Hell (1954).

Next the comique troupier (barrack comedy film). This also experienced several years of popularity thanks to such film-makers as Fernand Rivers (Tire au flanc/The Sad Sack, 1950), André Berthomieu (Pigalle-Saint-Germain-des-Prés, 1950) or Émile Couzinet (Trois marins dans un couvent, 1949; Trois jours de bringue à Paris, 1953; Mon curé champion du régiment, 1955; Trois marins en bordée, 1957) - all film-makers who were able to set up their own production companies thanks to the financial gains gener- ated by automatic aid.

Then there is the costume drama (e.g. Fanfan la Tulipe (Christian-Jaque, 1952)). Interestingly, this type of production allowed for some of the B-rated film-makers to create more crafted pieces of work. André Hunebelle, after several undistinguished films, threw himself into high production value cloak-and-dagger films, contributing to the success of his production company (Les Trois mousquetaires/The Three Musketeers, 1952; Le Bossu/ The Hunchback of Paris, 1959; Le Capitan/Captain Blood, 1960). Many of these costume dramas are literary adaptations of Alexandre Dumas, a pop- ular author par excellence, who has been adapted to the screen no less than 312 times between the years 1898 and 2002 (with 65 adaptations of Le Comte de Monte Cristo and 34 of Les Trois mousquetaires). But a great many of these adaptations were made during the 1950s. Robert Vernay adapted Le Comte de Monte Cristo (1955), and Émile Couzinet the romantic drama Buridan, héros de la tour de Nesle (1952).

As far as other genres are concerned, the effort to attract audiences took a middle path: a popular cinema going for quality products (see Berthin-Maghit 2000: 47). Some film-makers 
turned to the French clas- sics for their adaptations and in this way contributed to the emergence of an academic cinema populated by stars (Jean Gabin, Michel Simon, Charles Vanel, Michèle Morgan, Danielle Darrieux). The scriptwriters Jean Aurenche and Pierre Bost adapted a significant number of literary classics, and did so with particular stars in mind. This was the so-called 'cinéma de qualité', hierarchically organized and fiercely guarded by a corporate body of unionists and bosses who pulled in a single direction to protect every- one's interests. The label derives from an article written by Jean-Pierre Barrot, entitled 'La Tradition de la qualité' and published in 1953 (Agel et al. 1953), so a year before Truffaut's famous diatribe. In this article, he listed films by Jean Delannoy, ChristianJaque, Jean Faurez and Henri Calef, warmly commenting on how they had helped to maintain audience numbers, and bringing together popular cinema and the cinema of quality, which did w ell abroad as well as in France, and thus contributed to the general good health of the French film industry.

Consequently, the French government was not particularly concerned about the actual quality of the cinema it funded, especially when film person- nel, who until recently had been seriously affected by three consecutive years of unemployment (brought about by the quota system), could once again find work in the film studios. ${ }^{4}$ So on this count, the majority of the unions and politicians deemed that the Fonds de soutien was a considerable success. However, without actually contesting the value of the Fonds de soutien, certain film critics began to dispute the automatic way in which the money was distributed. In their view, the poor quality (even vulgarity) of this French cinema was a direct consequence of the way support was allocated. The auteur polemic grew out of this issue, most famously formulated by the Cahiers du Cinéma group. Cahiers critics very quickly distanced themselves from this popular French cinema, the better to denounce the new 'cinema of quality' for what they considered to be its superficial nature, as well as its unwarranted tendency to take itself seriously in intellectual and aesthetic terms. For the historian of the New Wave, Antoine de Baecque,

these polemical issues that were at the heart of the Cahiers in the early ' 50 s were not just played out within the journal. Very often salvoes were directly targeted against French cinema ... perhaps as a way of consolidating the Cahiers family. In this way, the Cahiers was part of a vogue at the time where polemics were the acme of intellectual debate. (Baecque 1991: 89)

In 1951, André Bazin wrote about this system of support:

As things stand today, a producer who takes no risks and hires Fernandel's toothy grin for yet another Barnabé is bound to win on two counts, in that the money he obtains from the fund will be added onto that of the box-office tak- ings. The producer seeking to make a 'quality' film in theory runs a double, albeit unlikely, risk: first, the costs of making a quality film (often quite high); second, to see the promised funding disappear. So we can conclude, without prejudice, that the way in which the system of aid is currently implemented means that the least risky projects get funded, in other words mediocrity. (Bazin 1951: 6)

Bazin came back to this issue again in 1954, when, via what he called the 'carolinization of France', referring to the enormous popularity of Martine Carol and her often quite saucy films, he denounced the 'cultural chic' of this cinema built on the back of state funding, commenting that French 'quality cinema' was 'a prestige label stuck onto a mediocre prod- uct' (Bazin 1954: 29). For his part, François Truffaut accused producers of using literary adaptations for commercial reasons and to please the public, a view he expressed in his now famous article, 'A Certain Tendency of the French Cinema' (Truffaut 1954).

Apart from the obviously polemical nature of these statements, the demands they set out do indeed point to one of the major drawbacks of the system: namely that it prevented the emergence of new talent. New film- makers could not apply for aid since they had no track record. During the 1950s, the number of first films was low: eight in 1946, nine in 1954 and 1955, and on average ten to fifteen films per year, about 10 per cent of total production figures. Moreover, of those first films which did get there, there were few that one could qualify as popular. It was mostly a case of 
individual endeavours made by auteurs on the periphery of the system, such as Agnès Varda, Georges Rouquier, Pierre Schoendoerffer, Jean Rouch, Alexandre Astruc, Pierre Kast, Georges Franju, amongst others. These film-makers were, for the most part, self-financed and had to wait years for the necessary funding to make their first feature film (Rouquier, Varda, Melville). They were held in high esteem by the young critics, and some, notably Melville, were even revered. Some managed to get around the draconian strictures of the system of automatic aid; Melville by using a cooperative set-up, and Varda by establishing a shares system where wages were paid from profits made. Thus, although we must readily recognize its success, this automatic funding system did not really make it possible for the renewal of film genres, of auteurs and film-makers.

On 6 August 1953, the government finally entered into the debate and asked the CNC to put in place (on an experimental basis to begin with) a new set of funds alongside automatic aid. This funding, which at first rewarded 'quality' short films, was extended in 1955 to feature-length films, and in 1959 became the Avance sur recettes (an advance given up front and based on projected box-office receipts), which is still in place today. When it started, the recipient for the Prime à la qualité (Reward for Quality) for the short film was decided by a commission made up of thirteen members (three representatives of the State, three representatives of the Association of Critics, three makers of short films, three producers of short films and the Director of the CNC). The new measure was fairly cautious since only 10 per cent of the Fonds de Soutien was made available for this fostering of quality (and represented a funding of a maximum of 80 short films in any year). However, its significance was considerable, since it estab- lished the principle that aid was not determined on the basis of commercial success. Film was no longer a simple commercial product; the State had henceforth endowed it with an intrinsic aesthetic value. This would have a significant impact on French film production and rebalanced the financial dynamics which up until this time had favoured popular cinema.

The first to benefit were makers of short-films for whom the aid was orig-inally conceived. A new generation of auteurs came to cinema and formed the 'Groupe des Trente' ('Group of Thirty'). This generic term designated some thirty film-makers who published a manifesto on 20 December 1953. They established an association on 2 September 1954 and held their first Annual General Meeting on 18 October of that year. Without in any way attempting to replace established unions, this group prohibited any state intervention in matters of creativity and any final institutionalization of the Reward for Quality, which at this stage was still only at an experimental stage. The effect of this introduction of the Reward for Quality (with its qual- ifying precepts) was that the word 'culture' now found itself aligned with the 'public interest' and 'public service', values which the CNC now found itself entrusted to defend (see Léglise 1969). The other merits of this system, where filmmakers were concerned, was that it offered them an entry into the profession without having to go through the traditional route of appren- ticeship to films in production. Indeed, the Reward for Quality made it possi- ble to get the short film-maker's professional card that was indispensable for work. After two short films, you were qualified for the feature film-maker's card - a good way of short-circuiting the apprenticeship route.

Henceforth, the notion of quality was defined in relation to (and increasingly in opposition to) commercial success. This alignment contri- buted to the gradual association of popular cinema with commercialism and, with it, film-makers who had managed to make a success of their careers in this domain, such as Tourneur, Grémillon, Le Chanois, Cayatte, amongst others (see Sorlin 2000: 19). In the following years, the gulf between the two types of cinema broadened; on the one hand there was popular cinema with its automatic aid, and on the other the thinking person's cinema with its funding for quality. A special chain of cinemas opening in the late 1950s (the AFCAE) made it possible for this latter cinema, labelled variously as 'difficult', 'independent', or 'thought-provoking', to create for itself a separate identity, known as 'Art et Essai'.

It is undoubtedly thanks to the Group of Thirty that the principle of extending aid to full-length feature films occurred in 1955. Even though the short film never knew the Golden Age that so 
many film-makers had wished for, at least as Alain and Odette Virmaux tell us, "production of films in the second half of the 1950s in France was nonetheless particu- larly spectacular and the funding of quality was certainly a contributing factor' (Virmaux 1994: 778).

Finally, and paradoxically, the 1950s, which were the Golden Age for popular French cinema, indirectly prepared the ground for the auteur cine- ma of the following decade. On the one hand, by contributing in substantial economic terms to the Fonds de soutien, from 1953 onwards, it greatly assisted in funding the Reward for Quality aid system; on the other, by acting as the catalyst that brought others to push state legislation to encompass a broader remit for film-making, it indirectly made space for a less commercial cinema. Certainly this progress was due to the Group of Thirty, but also to the pressure exercised by cinema-lovers. Apart from the auteur debate and what it advocated, there was also the determination of the young Turks writing for the Cahiers $d u$ Cinéma-especially Truffaut, Chabrol, Rivette, Godard and Rohmer, who were later to become the core of the French New Wave - to expose the utilitarianism of popular cinema and, in particular, those film-makers who had managed to exploit the aid system to their own advantage. Having said this, we should perhaps not forget that the history of cinema tells us that within any practice of attacking an established cinema there lies also the seeds of a younger generation anxious to get its hands on the means of production themselves. It also tells us that boundaries are less distinct than one might be led to believe between popular cinema and its more radical counterpart; often those who were once the young hotheads are now the very same people who make today's popular cinema. (Translated by Susan Hayward)

\section{References}

Agel, H., Barrot, J.-P. and Doniol-Valcroze, J. (1953), Sept ans de cinéma, Paris: Cerf. de Baecque, A. (1991), Les Cahiers du Cinéma: histoire d'une revue. Tome I: À l'assaut du cinéma (1951-1959), Paris: Cahiers du cinéma.

Bazin, A. (1951), 'La difficile définition de la qualité', Radio-Télévision-Cinéma, 64, p. 6.

_(1954), 'De la carolinisation de la France', Esprit, 22, pp. 298-304. Berthet, F. (2000), 'Questions d'histoire économique', in J.-P. Berthin-Maghit (ed.),

Les Cinémas européens des années cinquante, Paris: AFRHC, pp. 117-26.

Berthin-Maghit, J.-P. (1994), Le Cinéma français sous l'Occupation, Paris: Presses Universitaires de France.

(2000), 'Prolégomènes à une étude du cinéma français des années cinquante', in J.-P. Berthin-Maghit (ed.), Les Cinémas européens des années cinquante, Paris: AFRHC, pp. 47-54.

Brochand, C. (1994), Histoire générale de la Radio et de la Télévision en France (Tome 1 et 2), Paris: Comité d'Histoire de la Radiodiffusion, La Documentation française.

Darré, Y. (2002), Histoire sociale du cinéma français, Paris: La Découverte.

Eveno, P. (ed.) (1985), 'L'Histoire au jour le jour, tome 2: 1955-1962: le temps des ruptures', Le Monde dossiers et documents.

Goetschel, P. and Loyer, E. (1994), Histoire culturelle et intellectuelle de la France au XX siècle, Paris: Armand Colin.

Guillaume, S. (1989), La France contemporaine: chronologie commentée (1946-1990), Tome 1: La IV République, Paris: Perrin.

Heinz, G. and Peterson, A. (1974), The French Fifth Republic: Establishment and Consolidation 1958-1965, Stanford, CA: Hoover Institution Press.

Hubert-Lacombe, P. (2000), Le Cinéma français dans la guerre froide 1946-1956, Paris: L'Harmattan.

Jeancolas, J.-P. (1983), Quinze ans d'années trente: le cinéma des Français 1929-1944, Paris: Stock.

Léglise, P. (1969), Histoire de la politique du cinéma français, tome 2: Entre deux Républiques 1940-1946, Paris: Librairie générale de droit et de jurisprudence.

Levy, M.-F. (ed.) (1999), La Télévision dans la République: les années 50, Brussels: Complexe.

Mayol, P. (1995), 'Consommateurs, encore un effort', in J.-C. Klein and

P. Gumplowicz (eds), Paris 1944-1954: artistes, intellectuels, publics: la culture comme enjeu, Paris: Autrement, pp. $30-41$.

Nicolas, B. (1997), 'Logique d'entreprise ou logique professionnelle: pratiques syndicales des ouvriers du cinéma', in P.-J. Benghozi and C. Delage (eds), Une histoire économique du cinéma français, Paris: L'Harmattan, pp. 285-304.

Poujol, G. and Romer, M. (eds) (1996), Dictionnaire biographique des militants: de l'Éducation populaire à l'action culturelle XIXe-XXe siècles, Paris: L'Harmattan.

Rioux, J.-P.(1983), La France de la Quatrième République: l'Expansion etl'Impuissance, 1952-1958, Paris: Seuil.

Segrestin, D. (1975), 'Du syndicalisme de métier au syndicalisme de classe: pour une sociologie de la CGT', Sociologie du travail, 2, pp. 152-76.

(1985), Le Phénomène corporatiste: essai sur l'avenir des systèmes profession-nels fermés en France, Paris: Fayard.

Sorlin, P. (2000), 'Ce qu'était un film populaire dans l'Europe des années cinquante', in J.-P. Bertin Maghit (ed.), Les Cinémas européens des années cinquante, Paris: AFRHC, pp. 19-46.

Thorez, M. (1964), Euvres (mars-novembre 1946), livre 5, tome 20, Paris: Éditions Sociales.

Truffaut, F. (1954), 'Une certaine tendance du cinéma français', Cahiers du Cinéma, 31, pp. 15-29.

Verdes-Leroux, J. (1987), Le Réveil des somnambules: le Parti communiste, les intellectuels et la culture 1956-1985, Paris: 
Fayard/Minuit.

Vincent, G. (1977), Les Français 1945-1975: chronologie et structures d'une société, Paris: Masson.

Virenque, A. (1990), L'Industrie cinématographique française, Paris: Presses Universitaires de France.

Virmaux, A. and O. (1994), Dictionnaire du cinéma mondial, Paris: Rocher.

\section{Contributor details}

Frédéric Gimello-Mesplomb is Associate Professor at the University of Metz and a researcher at the CNRS. He also teaches at Sciences Po, the Paris Institute of Political Studies. His research specialism is in French and European public film policies (analysis of public policy-led interventions in the national film industry), economic history of film and cultural representations through film. Contact: Université de Metz, Département Arts et Culture, UFR Sciences Humaines et Arts, Ile du Saulçy, 57000 METZ, France.

E-mail: gimello@univ-metz.fr 